ACTA UNIVERSITATIS NICOLAI COPER NICI

DOI: http://dx.doi.org/10.12775/AUNC_ECON.2014.018 EKONOMIA XLV nr 2 (2014) 289-312

Pierwsza wersja złożona 28 lutego 2014

ISSN

Końcowa wersja zaakceptowana 20 grudnia 2014

2080-0339

Matgorzata Podogrodzka*

\title{
PROCESY DEMOGRAFICZNE W WYBRANYCH MIASTACH POLSKI Z LICZBĄ LUDNOŚCI POWYŻEJ 100 TYS.
}

Z a r y s t r e ś c i. Od początku lat 90. różna dynamika zmian w liczbie ludności obserwowana w miastach Polski wynika z różnego natężenia procesów demograficznych, tj. płodności, umieralności oraz migracji. Celem artykułu jest ocena, w jakim stopniu procesy te warunkują zmianę liczby ludności oraz czy wielkość miasta, rozumiana jako liczba mieszkańców, określa te zmiany. W rozważaniach wykorzystano informacje o wybranych dziesięciu miastach położonych w różnych częściach kraju, których liczba ludności przekracza 100 tys. Analiza prowadzona jest $\mathrm{z}$ wykorzystaniem liniowej funkcji trendu, indeksów dynamiki oraz listy rankingowej.

S ło w a k l u c z o w e: demografia, miasta Polski, ludność.

K l a s fik ac j a JEL: O11, R11.

\section{WSTĘP}

Przekształcenia społeczno-gospodarcze dokonujące się w Polsce od przeszło dwudziestu lat nie omijają również miast, zarówno tych dużych (Majdzińska, 2011), jak i tych małych (Podogrodzka, 2013). Jednocześnie zmiany te wpisują się w teorię drugiego przejścia demograficznego, która omawia proces przejścia z reprodukcji ludności tradycyjnej (rozszerzonej) do nowoczesnej (oszczędnej) (Okólski, 2004). Wśród głównych determinant kształtujących te przemiany wymienia się wiele czynników, które można

\footnotetext{
* Adres do korespondencji: Małgorzata Podogrodzka, Szkoła Główna Handlowa, Instytut Statystyki i Demografii, ul. Madalińskiego 6/8, 02-513 Warszawa, e-mail: Malgorzata.Podogrodzka@sgh.waw.pl.

(C) 2014 Uniwersytet Mikołaja Kopernika. All rights reserved. http://www.aunc.ekonomia.umk.pl
} 
sklasyfikować w trzy grupy, tj. strukturalne (m.in. industrializacja, urbanizacja, opieka zdrowotna), kulturowe (m.in. rozwój demokracji, zmiany wartości norm i wartości społecznych) czy technologiczne (telekomunikacja, informacja, antykoncepcja) (Kotowska i inni, 2008). Jednocześnie każdy z tych elementów w nieco odmienny sposób wpływa na procesy demograficzne. Ponieważ nasze rozważania dotyczą jedynie zmiany liczby ludności w wybranych miastach Polski w wyniku ruchu rzeczywistego ludności, rozważania na ten temat zostały pominięte.

Jednakże kogo można (należy) uznać za mieszkańca miasta? Czy jest to osoba stale w nim przebywająca? A może również i ta, która okresowo w nim mieszka w wyniku wykonywania pracy zawodowej czy pobierania nauki? W naszych rozważaniach przyjmujemy, iż jest to osoba zameldowana $\mathrm{w}$ danym mieście. Podejście to wynika $\mathrm{z}$ dwóch przesłanek. Po pierwsze, osoba ta ponosi określone koszty związane $\mathrm{z}$ funkcjonowaniem miasta. Równocześnie poprzez zameldowanie identyfikuje się z tym ośrodkiem oraz w znacznej mierze korzysta $\mathrm{z}$ jego infrastruktury. Po drugie, z możliwości pozyskania danych statystycznych $w$ interesującym nas zakresie.

Celem artykułu jest ukazanie zmian w liczbie ludności w wybranych miastach Polski, z liczbą ludności powyżej 100 tys., w latach 1990-2010 oraz opis procesów demograficznych je kształtujących. Opis ten pozwoli na weryfikację następujących hipotez badawczych:

H1 W badanych miastach Polski, które odznaczały się relatywnie dużą licz-

bą osób w nich zamieszkałych, spadek liczby mieszkańców wynikał przede wszystkim z ujemnego w nich przyrostu naturalnego. Natomiast w tych miastach, gdzie liczba mieszkańców była relatywnie niewielka, głównie z ujemnego salda migracji.

H2 W badanych miastach Polski, które charakteryzują się relatywnie dużą liczbą mieszkańców, wzrost liczby mieszkańców wynikał przede wszyst$\operatorname{kim} \mathrm{z}$ dodatniego salda migracji. Natomiast $w$ miastach z nieco mniejszą liczbą mieszkańców, głównie z dodatniego przyrostu naturalnego.

Do analizy wybrano dziesięć miast, tj. Warszawę, Łódź, Kraków, Wrocław, Gdańsk, Szczecin, Chorzów, Kalisz, Koszalin i Legnicę. Ośrodki te charakteryzują się różną liczba mieszkańców, ale wszystkie mają ich powyżej 100 tys. oraz położone są w różnych częściach Polski. Jednocześnie łącznie stanowią one 25\% wszystkich miast Polski z taką liczbą mieszkańców. Wydaje się, że uzyskane wyniki mogą stanowić pierwszy krok w ocenie przebiegu procesów demograficznych w tych miastach ogółem. Jednocześnie przyjmujemy, że mówiąc miasta z małą liczbą mieszkańców, mamy na myśli te ośrodki miejskie, w których liczba osób w nich zamieszkałych jest jedynie nieco wyższa niż 100 tys., a w sytuacji, gdy mówimy miasta 
z dużą liczbą mieszkańców, myślimy o tych, gdzie liczba ta jest zdecydowanie wyższa od tej wartości. Wybrane do analizy miasta dodatkowo odznaczają się odmiennym poziomem rozwoju ekonomicznego, który jest bezpośrednim czynnikiem wpływającym na omawiane procesy demograficzne (Kałuża-Koptas, 2014; Matusik i inni, 2012; Wróbel, 2011).

Do opisu procesów demograficznych wykorzystaliśmy takie miary, jak: współczynnik małżeńskości i współczynnik rozwodów ${ }^{1}$ oraz rozkład cząstkowych współczynników małżeńskości według wieku nowożeńców ${ }^{2}$, współczynnik płodności ${ }^{3}$ oraz cząstkowe współczynniki płodności według wieku matki w chwili rodzenia, współczynnik umieralności ${ }^{4}$ oraz cząstkowe współczynniki umieralności według wieku, współczynnik przyrostu naturalnego ${ }^{5}$, współczynnik salda migracji ${ }^{6}$. Analiza prowadzona jest w dwóch ujęciach: pierwsze zawiera opis dynamiki zmian wyróżnionych miar demograficznych. W tym celu wykorzystamy liniową funkcję trendu (aby określić kierunek odnotowanych zmian $\mathrm{w}$ badanym okresie) oraz indeksy dynamiki (aby określić natężenie zmian między początkiem a końcem badanego okresu). Drugie podejście obejmuje opis relacji między wartościami analizowanych miar. W tym przypadku zbudowano listę rankingową ośrodków miejskich według rosnących wartości wyznaczonych współczynników demograficznych.

Informacje wykorzystane w analizie pochodzą z Roczników Demograficznych z różnych lat okresu 1990-2010.

\section{ZMIANY LICZBY MIESZKAŃCÓW W WYBRANYCH MIASTACH POLSKI}

W latach 1990-2010 obserwowana dynamika zmian liczby ludności w wyróżnionych miastach Polski nie zależała od liczby osób w nich za-

\footnotetext{
${ }^{1}$ Współczynnik zawierania małżeństw (rozwodów) wyraża stosunek liczby zawartych (rozwiązanych formalnie) małżeństw w okresie t na 1 tys. ludności.

${ }^{2}$ Proces zawierania i rozpadu małżeństw nie jest bezpośrednim czynnikiem wpływającym na zmiany liczby ludności, ale pośrednio wpływa na zmiany w dzietności. Obecnie około $70 \%$ wszystkich urodzeń pochodzi ze związków małżeńskich. W okresie wcześniejszym odsetek ten był jeszcze wyższy.

${ }^{3}$ Współczynnik płodności wyraża liczbę urodzonych dzieci w okresie t na 1 tys. kobiet $\mathrm{w}$ wieku prokreacyjnym, tj. w wieku 15-49 lat na koniec badanego okresu.

${ }^{4}$ Współczynnik zgonów liczony jest jako iloraz liczby zgonów w okresie t na 1 tys. ludności na koniec badanego okresu.

${ }^{5}$ Współczynnik przyrostu naturalnego to iloraz różnicy między liczbą urodzeń a zgonów w okresie $\mathrm{t}$ w przeliczeniu na 1 tys. ludności na koniec badanego okresu.

${ }^{6}$ Współczynnik salda migracji liczymy jako iloraz różnicy między napływem a odpływem ludności w okresie t w przeliczeniu na 1 tys. ludności na koniec badanego okresu.
} 
mieszkałych. Charakteryzowała się ona różnym natężeniem oraz kierunkiem. Opisując zmiany te liniową funkcją trendu ${ }^{7}$ uzyskujemy następujące wyniki (tabela 1 ).

Tabela 1. Liniowa funkcja trendu współczynników zawierania małżeństw w wybranych miastach Polski w latach 1990-2010

\begin{tabular}{ccc}
\hline Miasto & Liniowa funkcja trendu & Współczynnik determinacji \\
\hline Chorzów & $-1,0 \cdot t+131,6$ & 0,97 \\
Gdańsk & $-0,39 \cdot t+464,6$ & 0,72 \\
Kalisz & $+0,07 \cdot t+106,8$ & 0,16 \\
Koszalin & $-0,22 \cdot t+112,1$ & 0,50 \\
Kraków & $+0,70 \cdot t+742,4$ & 0,34 \\
Legnica & $-0,15 \cdot t+108,2$ & 0,28 \\
Łódź & $-5,80 \cdot t+860,2$ & 0,95 \\
Szczecin & $-0,54 \cdot t+419,9$ & 0,58 \\
Warszawa & $+4,4 \cdot t+1613,0$ & 0,51 \\
Wrocław & $-0,57 \cdot t+644,4$ & 0,85 \\
\hline
\end{tabular}

Źródło: obliczenia własne na podstawie danych z Roczników Demograficznych z różnych lat; GUS, Warszawa.

Średnio z roku na rok możemy mówić o wzroście liczby mieszkańców Warszawy ${ }^{8}$, Kalisza i Krakowa. Pod koniec badanego okresu było w nich więcej odpowiednio o $3,7 \%$; $0,6 \%$ i $0,9 \%$ osób niż na jego początku. W pozostałych ośrodkach odnotowujemy odwrotną sytuację, a najwyraźniejszy spadek liczby mieszkańców zaobserwowano w Łodzi i Chorzowie. W ośrodkach tych ubyło w ciągu dwudziestu lat około 13\% i 14,5\% ludności (rysunek 1).

Zmiany liczby ludności wynikają bezpośrednio z różnego natężenia płodności, umieralności oraz ruchu wędrówkowego ludności oraz pośrednio ze skłonności do zawierania małżeństw oraz ich rozpadu. Wśród głównych determinant ${ }^{9}$ kształtujących te procesy wymienia się m.in. wzrost poziomu życia mieszkańców miast, wzrost poczucia bezpieczeństwa socjalnego, rosnącą mobilność społeczną i przestrzenną, dynamicznie zmieniającą się sytuację na rynku pracy, wzrost dostępu i poprawę jakości ochrony zdrowia,

\footnotetext{
${ }^{7}$ Wartości współczynników liniowej funkcji trendu wyrażone są w tysiącach.

${ }^{8} \mathrm{~W}$ ostatnich dwóch dekadach Warszawa dwukrotnie zwiększała swoją powierzchnię. Przyłączone zostały sąsiednie miejscowości. Spowodowało to gwałtowną zmianę jej liczby mieszkańców, zwłaszcza w 2002 roku.

${ }^{9}$ Podobny do obserwowanego dla Polski przebieg procesów demograficznych rozpoczął się w krajach europejskich prawie trzy dekady wcześniej. Uznaje się, że czynniki wpływające na te zmiany są podobne we wszystkich krajach, ale ich wpływ na natężenie tych procesów może być odmienny.
} 
wzrost znaczenia metod i środków kontroli urodzeń, społeczną akceptację bezdzietności, wzrost poziomu wykształcenia, zwiększone uczestnictwo kobiet $\mathrm{w}$ życiu społecznym, zmniejszenie znaczenia małżeństwa i wzrost związków nieformalnych, większą niezależność współmałżonków oraz rosnące trudności łączenia ról partnera i rodzica, wzrost znaczenia samorealizacji (zob. Okólski, 1990; Cigno, 1991; Cliquet, 1991; Rószkiewicz, 1991; Kotowska, 1999). W dalszej części artykuł omówimy przebieg tych procesów oraz przeprowadzimy ocenę ich wpływu na zmieniającą się liczbę mieszkańców omawianych miast Polski.

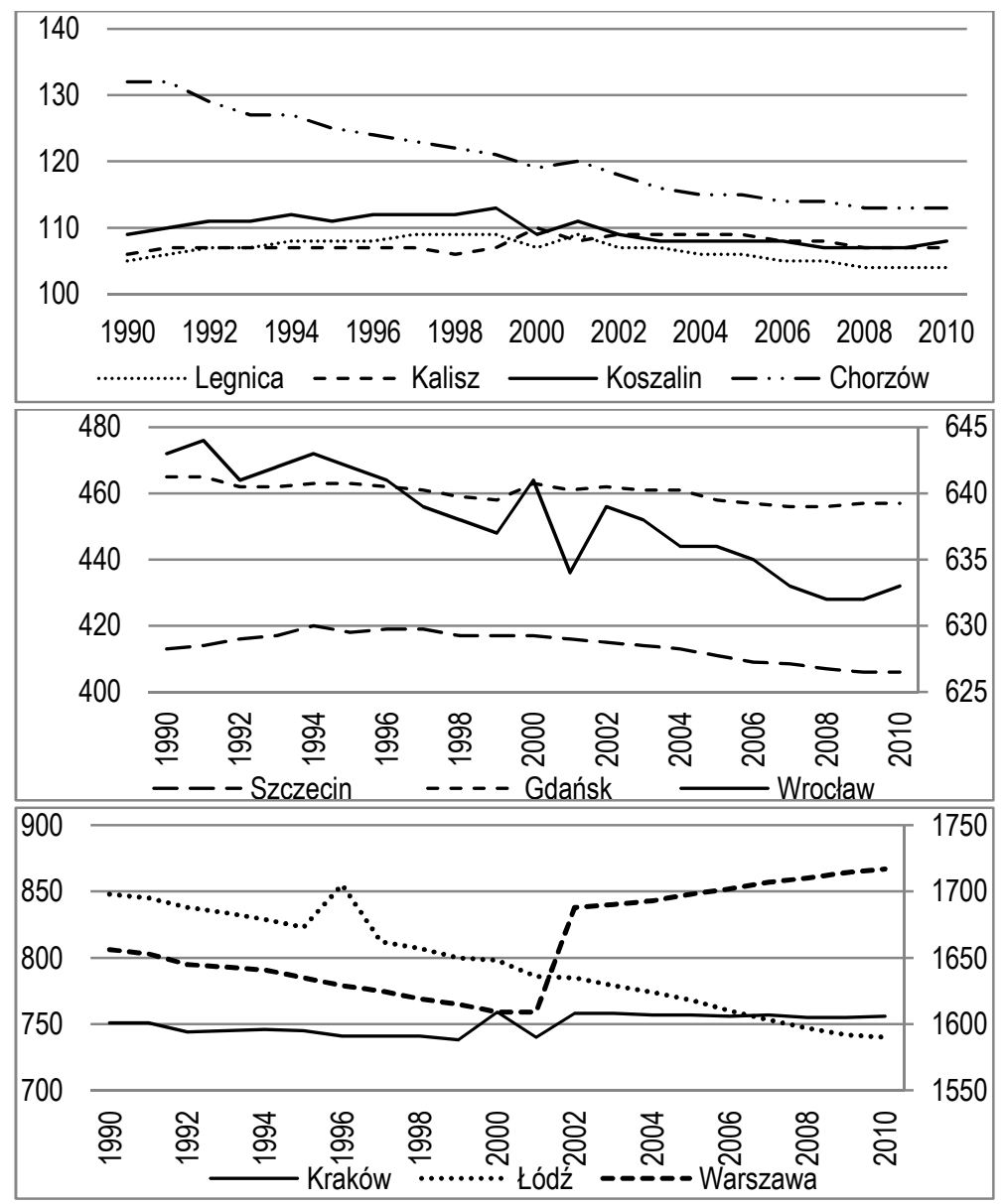

Rysunek 1. Liczba ludności w wybranych miastach Polski w latach 1990-2010 (w tys.)

Źródło: Rocznik Demograficzny z różnych lat; GUS, Warszawa. 


\section{PROCES ZAWIERANIA ORAZ ROZPADU MAEŻEŃSTW W WYBRANYCH MIASTACH POLSKI}

W ostatnich dwóch dekadach we wszystkich analizowanych miastach Polski współczynniki zawierania małżeństw podlegały licznym wahaniom w czasie, ale o podobnym kierunku ich przebiegu, natomiast o nieco odmiennym ich natężeniu. Mniej więcej co pięć lat następował wzrost, a po tym okresie spadek skłonności do zawierania małżeństw, co wskazuje na pewną cykliczność tego zjawiska (rysunek 2).

Do uogólnionego opisu kierunku oraz natężenia zmian procesu zawierania małżeństw wykorzystaliśmy liniową funkcję trendu, którą wyznaczyliśmy dla lat 1990-2010 oraz dla podokresu 1990-2002 oraz 2003-2010. Rok 2003 charakteryzuje się najniższym natężeniem wartości tej miary oraz jest to wyraźnie zaznaczony punkt zwrotny dla odwrócenia trendu w porównaniu do wcześniej obserwowanej tendencji.

W pierwszym z podokresów we wszystkich analizowanych miastach obserwujemy spadek skłonności do zawierania małżeństw. Najniższą dynamiką charakteryzował się Kraków, a następnie Warszawa, Wrocław, Legnica, Koszalin, Szczecin, Łódź, Gdańsk, Chorzów i Kalisz. Zasadniczo, im miasto z większą liczbą mieszkańców, tym intensywność tych zmian mniejsza. W kolejnym podokresie odnotowujemy już wzrost skłonności do zawierania małżeństw, ale był on najmniej wyraźny w Warszawie, a następnie w Kaliszu, Gdańsku, Łodzi, Krakowie, Legnicy, Szczecinie, Wrocławiu, Chorzowie i Koszalinie. Zatem i tym razem zmiany te nie zależały od liczby mieszkańców tych ośrodków. W konsekwencji różne nasilenie przekształceń współczynnika małżeńskości spowodowało, że między rokiem 1990 a 2010 w połowie analizowanych miast odnotowujemy wyraźny spadek natężenia małżeńskości, który był najsilniejszy w Kaliszu, a następnie w Legnicy, Gdańsku, Koszalinie i Chorzowie. Natomiast nieznaczny wzrost skłonności do zawierania małżeństw wystąpił - na podobnym poziomie - w Krakowie, Warszawie i Łodzi oraz - nieco intensywniejszy - we Wrocławiu i Szczecinie. Można zatem stwierdzić, że im miasto z mniejszą liczbą ludności, tym spadek skłonności do zawierania małżeństw był nieco wyraźniejszy. Równocześnie z czasem znacznie zmalały różnice w wartościach współczynników małżeńskości między analizowanymi miastami. Stały się one zatem nieco bardziej podobne ze względu na omawianą charakterystykę (tabela 2). 


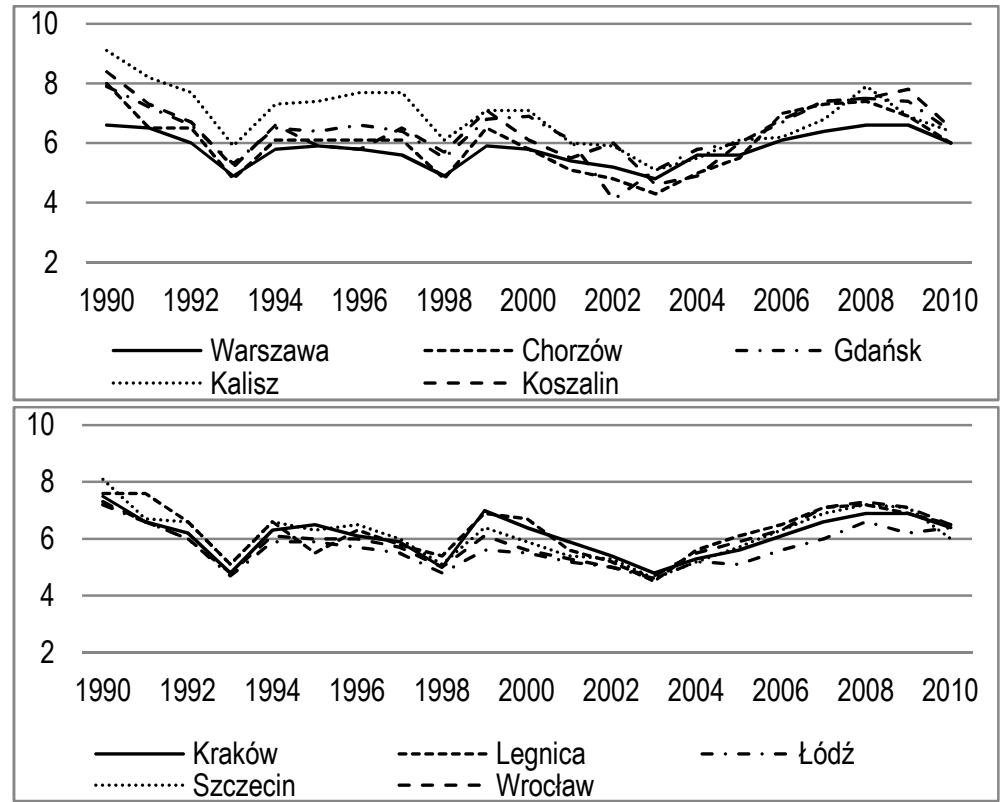

Rysunek 2. Współczynniki zawierania małżeństw w wybranych miastach Polski w latach 1990-2010 (na 10 tys. ludności)

Źródło: Rocznik Demograficzny z różnych lat; GUS, Warszawa.

Tabela 2. Liniowa funkcja trendu współczynników zawierania małżeństw w wybranych miastach Polski w latach 1990-2010

\begin{tabular}{ccccccc}
\hline \multirow{2}{*}{ Miasto } & \multicolumn{3}{c}{ Liniowa funkcja trendu dla lat } & \multicolumn{3}{c}{ Współczynnik determinacji dla lat } \\
\cline { 2 - 6 } & \multirow{2}{*}{$1990-2010$} & \multirow{2}{*}{$1990-2002$} & $2003-2010$ & $1990-$ & $1990-$ & $2003-$ \\
\hline Chorzów & $+0,00 \cdot t+6,03$ & $-0,15 \cdot t+6,96$ & $0,33 \cdot t+4,71$ & 0,00 & 0,39 & 2010 \\
Gdańsk & $-0,01 \cdot t+6,41$ & $-0,20 \cdot t+7,58$ & $0,27 \cdot t+5,34$ & 0,01 & 0,32 & 0,48 \\
Kalisz & $-0,08 \cdot t+7,75$ & $-0,17 \cdot t+8,36$ & $0,26 \cdot t+5,18$ & 0,25 & 0,46 & 0,55 \\
Koszalin & $-0,01 \cdot t+6,41$ & $-0,12 \cdot t+7,19$ & $0,39 \cdot t+4,67$ & 0,01 & 0,28 & 0,65 \\
Kraków & $-0,01 \cdot t+6,14$ & $-0,07 \cdot t+6,58$ & $0,28 \cdot t+4,81$ & 0,01 & 0,14 & 0,79 \\
Legnica & $-0,01 \cdot t+6,32$ & $-0,11 \cdot t+7,02$ & $0,29 \cdot t+4,99$ & 0,01 & 0,27 & 0,63 \\
Łódź & $-0,01 \cdot t+5,79$ & $-0,12 \cdot t+6,51$ & $0,27 \cdot t+4,51$ & 0,01 & 0,46 & 0,97 \\
Szczecin & $-0,02 \cdot t+6,35$ & $-0,14 \cdot t+7,13$ & $0,29 \cdot t+4,82$ & 0,02 & 0,43 & 0,58 \\
Warszawa & $+0,01 \cdot t+5,70$ & $-0,07 \cdot t+6,25$ & $0,20 \cdot t+5,07$ & 0,01 & 0,32 & 0,63 \\
Wrocław & $+0,02 \cdot t+5,74$ & $-0,11 \cdot t+6,59$ & $0,30 \cdot t+4,93$ & 0,04 & 0,40 & 0,69 \\
\hline
\end{tabular}

Źródło: obliczenia własne na podstawie danych z Roczników Demograficznych z różnych lat; GUS, Warszawa.

Reasumując, w badanym okresie liczba osób zamieszkałych w mieście determinowała dynamikę zmian współczynnika zawierania małżeństw. 
W tych ośrodkach miejskich, gdzie liczba mieszkańców była relatywnie duża, zmiany te były mniej wyraźne niż w tych ośrodkach, gdzie liczba mieszkań była znacznie mniejsza. Jednocześnie zmiany te zasadniczo nie wpłynęły na relacje między tymi ośrodkami. Stale najczęściej małżeństwa zawierane były w Szczecinie i Wrocławiu, a najrzadziej w Chorzowie i Warszawie. Tym samym liczba mieszkańców w tych miastach w małym stopniu wpływała na zmiany w skłonności do zawierania małżeństw, ale różna dynamika tych zmian spowodowała, że ośrodki te stały się nieco bardziej podobne ze względu na jej natężenie.

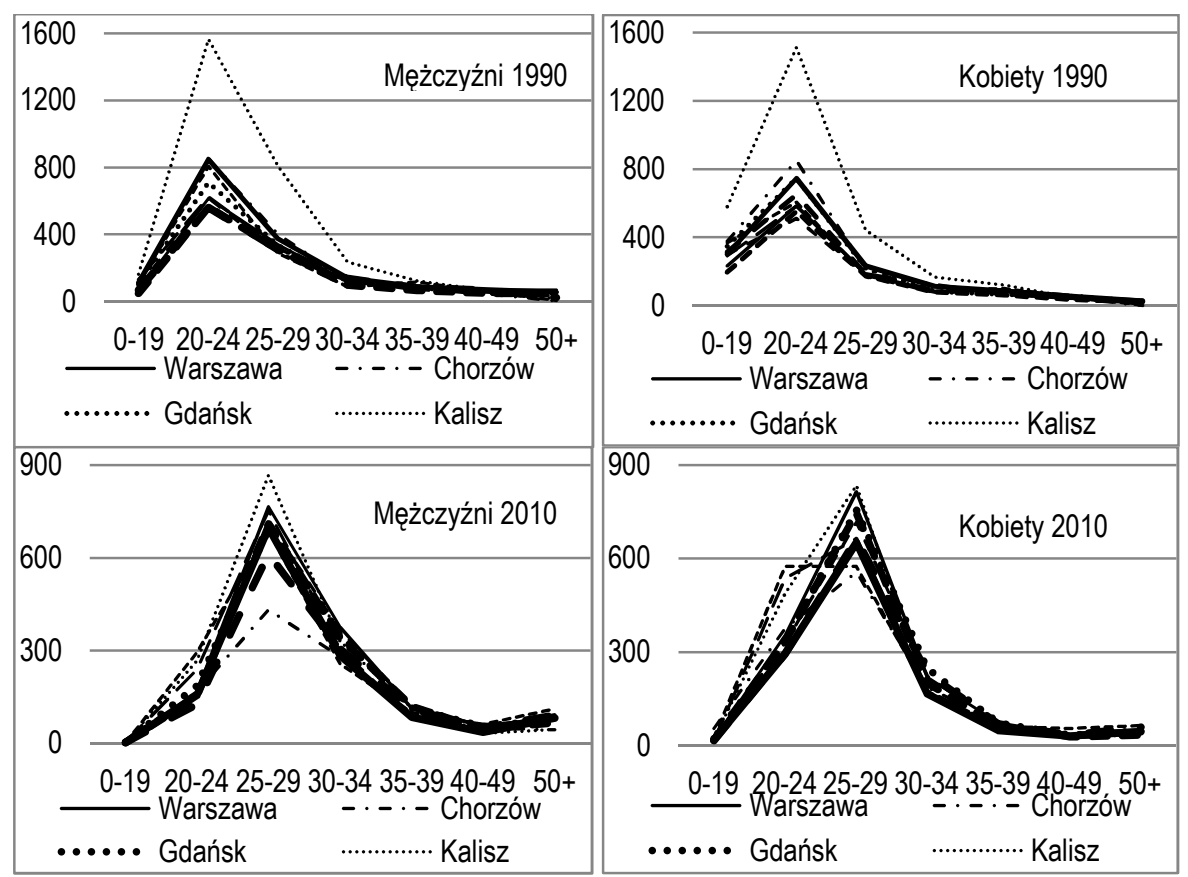

Rysunek 3. Wzorzec zawierania małżeństw w wybranych miastach Polski w roku 1990 i 2010 (na 10 tys. ludności)

Źródło: Rocznik Demograficzny z różnych lat; GUS, Warszawa.

Na obserwowane zmiany w skłonności do zawierania małżeństw w różnym stopniu wpływają przekształcenia w cząstkowych współczynnikach małżeńskości według wieku i płci nowożeńców. Między rokiem 1990 a 2010 w obu badanych populacjach (mężczyzn i kobiet) i prawie we wszystkich wyróżnionych miastach nastąpiło znaczące obniżenie natężenia zawierania małżeństw w grupie wieku 20-24 lata oraz wyraźny jego wzrost w grupie wieku 25-29 lat. Dodatkowo wzrost ten wystąpił również u mężczyzn 
w grupie wieku 30-34 lata. Wyjątek stanowi Legnica, gdzie w roku 2010 $\mathrm{u}$ kobiet natężenie zawierania małżeństw było podobne jak w grupie wieku 20-24 i 25-29 lat i na niewiele niższym poziomie jak w roku 1990. Przekształcenia te spowodowały tym samym, że w analizowanych ośrodkach miejskich wzorzec zawierania małżeństw stał się nieco bardziej podobny, co oznacza, że liczba mieszkańców w miasta w małym stopniu wpływała na zmiany w kształcie tego rozkładu (rysunek 3$)^{10}$.

Do oceny stopnia przekształceń wzorca małżeńskości między rokiem 1990 a 2010 wykorzystaliśmy relację między wartościami współczynnika zawierania małżeństw w grupie wieku 20-24 i 30-34 lata. Uznajemy, że jest on tym bardziej zaawansowany, im wartość tej miary w starszej grupie wieku są wyższe niż w grupie młodszej.

W populacji mężczyzn prawie we wszystkich rozważanych miastach współczynniki zawierania małżeństw w wieku 30-34 lata były wyższe niż w grupie 20-24 lata, a zwłaszcza w Krakowie, Warszawie, Szczecinie i Wrocławiu (o ponad 100\%). W Chorzowie, Gdańsku i Łodzi różnica ta wynosi 70-80\%, a w pozostałych ośrodkach miejskich około 30\%. Jedynie w Legnicy nadal skłonność do zawierania małżeństw była wyższa w młodszej grupie wieku. W zbiorowości kobiet nadal częściej małżeństwa zawierane były w wieku 20-24 lat niż 30-34 lata, ale najniższa różnica w natężeniu między tymi cząstkowymi współczynnikami małżeńskości wystąpiła w Gdańsku i Szczecinie (30\%) oraz we Wrocławiu, Krakowie i Warszawie (50-60\%). Najwyższa zaś dotyczyła Łodzi i Chorzowa (80-100\%) oraz Kalisza, Koszalina i Legnicy (ponad 100\%). Można zatem stwierdzić, że im miasto charakteryzowało się większą liczbą mieszkańców, tym przekształcenia wzorca małżeńskości były bardziej zaawansowane.

Podobnie jak współczynniki zawierania małżeństw, współczynniki rozwodów charakteryzują się licznymi wahaniami w czasie, ale o znacznie mniejszej amplitudzie, a ich przebieg był podobny we wszystkich rozważanych miastach (rysunek 4). Oznacza to, że liczba zawieranych związków wciąż przewyższa ich rozpad, ale relacje te kształtowały się nieco odmiennie w badanych ośrodkach miejskich.

\footnotetext{
${ }^{10}$ Dwa rysunki z lewej strony odnoszą się do mężczyzn, a kolejne dwa do kobiet.
} 


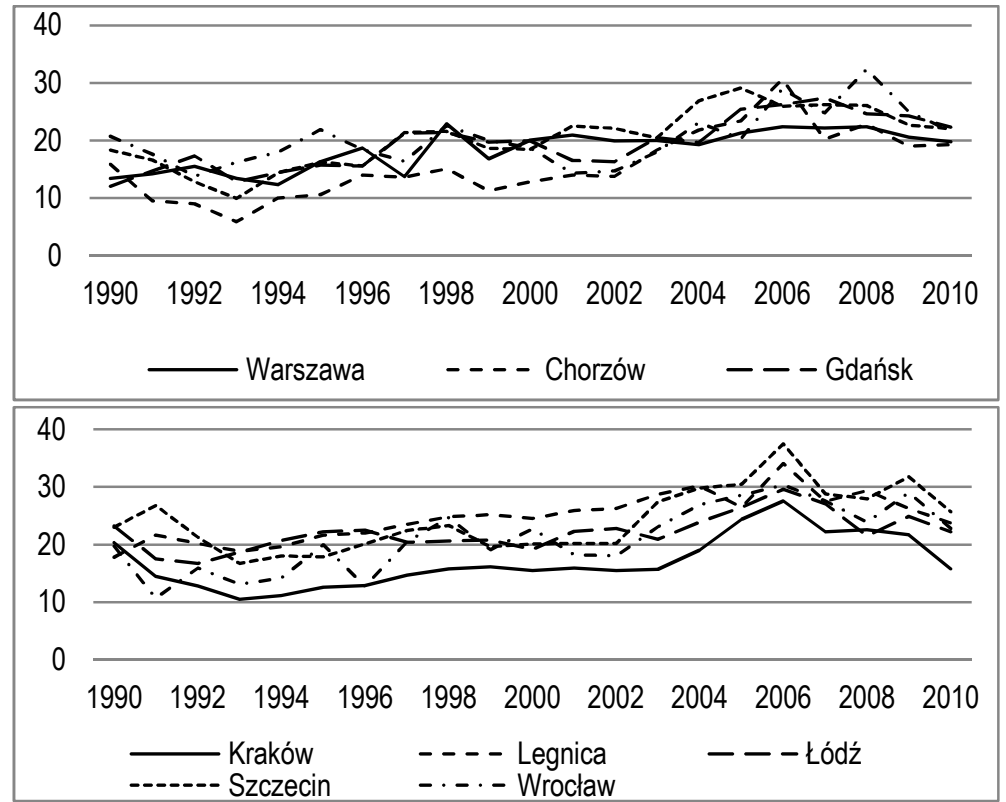

Rysunek 4. Współczynniki rozwodów w wybranych miastach Polski w roku 1990 i 2010 (na 10 tys. ludności)

Źródło: Rocznik Demograficzny z różnych lat; GUS, Warszawa.

Do syntetycznego opisu dynamiki rozwodów wyznaczyliśmy liniową funkcję trendu dla lat 1990-2010 ${ }^{11}$. We wszystkich miastach trend był dodatni. Średniorocznie natężenie rozwodów rosło najszybciej w Chorzowie i Wrocławiu, a następnie w Kaliszu i Gdańsku oraz w Szczecinie i Legnicy. Najniższe przyrosty odnotowano w Warszawie, Koszalinie, Krakowie i Koszalinie oraz Łodzi. Można zatem zauważyć, że liczba mieszkańców w miastach determinowała dynamikę rozpadu związków małżeńskich i im liczba ta była mniejsza, tym natężenie tych zmian było większe. To różne nasilenie zmian nieco zmieniło relacje między miastami. W 1990 roku najczęściej rozwodzono się w Łodzi i Szczecinie, a najrzadziej w Gdańsku i Warszawie. Dwie dekady później sytuacja ta dotyczy odpowiednio Szczecina i Legnicy oraz Krakowa i Chorzowa. O ile na początku badanego okre-

\footnotetext{
${ }^{11}$ Analizując natężenie współczynnika rozwodów w latach 1990-2010, należy zauważyć, że ostatnie pięć lat charakteryzuje się wyraźnym spadkiem wartości tej miary w wielu miastach, zwłaszcza tych o dużej liczbie mieszkańców. Jednakże w prowadzonej analizie nie dokonaliśmy jego podziału na dwa podokresy, ponieważ dla jednego z nich szereg czasowy byłby zbyt krótki.
} 
su możemy mówić, że liczba mieszkańców w miastach wpływała na natężenie rozwodów, to pod koniec badanego okresu czynnik ten nieco stracił na znaczeniu. Należy również zaznaczyć, że z czasem ośrodki miejskie stały się nieco mniej zróżnicowane ze względu na skłonność do rozwodów wśród ich mieszkańców (tabela 3).

Tabela 3. Liniowa funkcja trendu współczynników zawierania małżeństw w wybranych miastach Polski w latach 1990-2010

\begin{tabular}{ccc}
\hline Miasto & Liniowa funkcja trendu & Współczynnik determinacji \\
\hline Chorzów & $+0,73 \cdot t+7,71$ & 0,59 \\
Gdańsk & $+0,61 \cdot t+12,70$ & 0,70 \\
Kalisz & $+0,64 \cdot t+13,32$ & 0,63 \\
Koszalin & $+0,45 \cdot t+15,43$ & 0,34 \\
Kraków & $+0,47 \cdot t+11,80$ & 0,42 \\
Legnica & $+0,52 \cdot t+18,97$ & 0,62 \\
Łódź & $+0,31 \cdot t+18,65$ & 0,39 \\
Szczecin & $+0,57 \cdot t+17,98$ & 0,42 \\
Warszawa & $+0,45 \cdot t+13,48$ & 0,64 \\
Wrocław & $+0,72 \cdot t+13,16$ & 0,60 \\
\hline
\end{tabular}

Źródło: obliczenia własne na podstawie danych z Roczników Demograficznych z różnych lat; GUS, Warszawa.

We wszystkich analizowanych miastach z czasem obserwujemy spadek przewagi zawieranych małżeństw nad ich rozpadem, zwłaszcza w Chorzowie, Gdańsku i Kaliszu. Najwolniej proces ten postępował w Łodzi, Legnicy i Szczecinie, co wskazuje, iż liczba mieszkańców miast nie determinowała tych zmian, ale z czasem znacznie zmalała różnica w natężeniu tych skłonności między miastami.

\section{SKŁONNOŚĆ DO PROKREACJI W WYBRANYCH MIASTACH POLSKI}

Niezależnie od liczby mieszkańców w badanych miastach, współczynnik płodności wykazuje podobny kierunek zmian. W nieco dłuższym okresie niż pierwsza omawiana dekada systematycznie on malał, a w kolejnych latach rósł. Jednocześnie dynamika tych zmian nieco różniła się między ośrodkami miejskimi. Wyznaczając liniową funkcję trendu, można zauważyć, że w początkowych latach badanego okresu najszybciej wartości tej miary malały w Legnicy i Szczecinie, a następnie w Krakowie, Gdańsku i Koszalinie, Wrocławiu, Łodzi i Kaliszu oraz Chorzowie i Warszawie. Szybkość tych zmian nie zależała zatem od liczby mieszkańców w ośrodka miejskich. Od początku XXI wieku odnotowujemy wzrost współczynnika płodności, którego intensywność była najwyższa w Warszawie oraz Wrocławiu, a następnie - na podobnym poziomie - w Gdańsku i Krakowie, a już nieco niż- 
szym w Łodzi i Chorzowie, Szczecinie, Koszalinie i Legnicy oraz Kaliszu. Można zatem zauważyć, że im miasto z większą liczbą mieszkańców, tym również wyższa dynamika zmian współczynnika płodności. To różne nasilenie zmian sprawiło, że relacje między miastami zmieniły się w czasie. W latach 90. najwyższym natężeniem płodności odznaczały się takie miasta, jak: Legnica, Kalisz i Gdańsk, a najniższym: Warszawa, Łódź i Koszalin. Im miasto z mniejszą liczbą mieszkańców, tym skłonność do prokreacji większa. Dwie dekady później sytuacja ta dotyczyła odpowiednio: Warszawy, Gdańska i Wrocławia oraz Łodzi, Koszalina i Szczecina. Zatem im ośrodek z większą liczbą mieszkańców, tym wyższe wartości współczynnika płodności. Ponadto, w niektórych ośrodkach miejskich obserwowana płodność pod koniec badanego okresu była wyższa niż na jego początku. Należy do nich Warszawa, Wrocław, Łódź, Gdańsk i Chorzów. W pozostałych miastach wartość tej miary była już wyraźnie niższa, a zwłaszcza w Legnicy i Kaliszu (rysunek 5 i tabela 4).
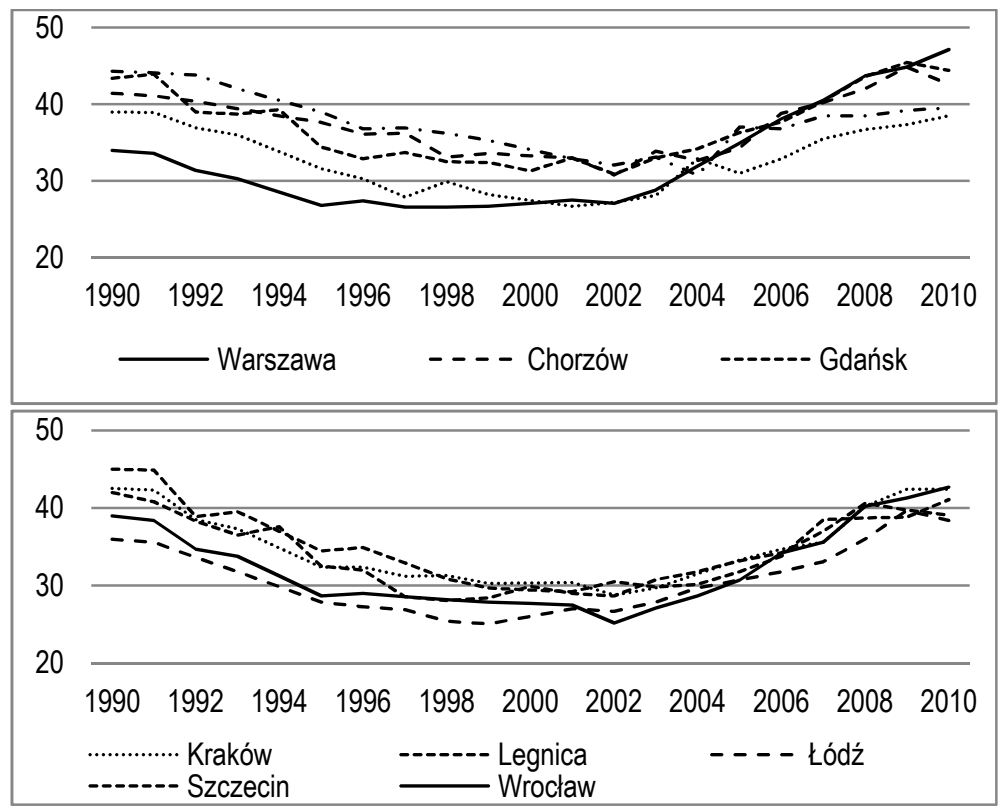

Rysunek 5. Współczynniki płodności dla kobiet w wieku 15-49 lat w wybranych miastach Polski w latach 1990-2010

Źródło: Rocznik Demograficzny z różnych lat; GUS, Warszawa.

Zmiany w wartości współczynnika płodności wynikają z różnego nasilenia cząstkowych współczynników płodności według wieku (wzorca płod- 
ności). Z czasem we wszystkich analizowanych miastach krzywa rozkładu płodności uległa wyraźnemu spłaszczeniu, dominanta przesunęła się do starszych grup wieku oraz zmniejszyły się różnice między współczynnikami płodności charakteryzującymi się najwyższą intensywnością. Jednocześnie ich stopień przekształceń zależał od liczb osób zamieszkałych w danym mieście. Jeżeli uznamy, że w roku 1990 stopień przekształceń wzorca był najwyższy w Warszawie (różnica między natężeniem płodności w grupie wieku 20-24 lata była jedynie nieznacznie wyższa niż w grupie 25-29 lat), to kolejną grupę w stopniu zaawansowania przekształceń wzorca tworzą takie miasta, jak: Wrocław, Gdańsk i Kraków. Wyższe natężenie płodności w grupie wieku 20-24 lata w porównaniu z grupą 25-29 lat odnotowujemy w Łodzi, Koszalinie, Szczecinie i Kaliszu, a jeszcze wyraźniejsze różnice między tymi grupami wieku wystąpiły w Legnicy i Chorzowie. W roku 2010 wzorzec płodności uległ wyraźnej zmianie. W Warszawie najwyższe natężenie płodności, na podobnym poziomie, dotyczyło grup wieku 25-29 oraz 30-34 lata. Nieznacznie wyższą płodność w grupie 25-29 odnotowujemy w Krakowie i Wrocławiu. Już nieco większe różnice między tymi grupami wiekowymi obserwujemy dla Szczecina, Gdańska, Łodzi i Koszalina. W pozostałych zaś miastach dominuje płodność w grupie 25-29 lat, a dodatkowo w Legnicy i Kaliszu była ona wyższa w grupie 30-34 lata niż w grupie 20-24 lata, a w Chorzowie kształtowała się na podobnym poziomie (rysunek 6).

Tabela 4. Liniowa funkcja trendu współczynników płodności w wybranych miastach Polski w latach 1990-2010

\begin{tabular}{ccccccc}
\hline \multirow{2}{*}{ Miasto } & \multicolumn{3}{c}{ Liniowa funkcja trendu dla lat } & \multicolumn{3}{c}{ Współczynnik determinacji dla lat } \\
\cline { 2 - 7 } & \multirow{2}{*}{$1990-2010$} & \multirow{2}{*}{$1990-2002$} & \multirow{2}{*}{$2003-2010$} & $1990-$ & $1990-$ & $2003-$ \\
& & & 2010 & 2002 & 2010 \\
\hline Chorzów & $+0,09+36,98$ & $-0,89+42,73$ & $+1,74+30,84$ & 0,01 & 0,97 & 0,88 \\
Gdańsk & $+0,09+36,12$ & $-1,06+43,24$ & $+1,91+30,77$ & 0,02 & 0,84 & 0,96 \\
Kalisz & $-0,31+41,07$ & $-1,09+45,95$ & $+1,11+31,65$ & 0,24 & 0,98 & 0,75 \\
Koszalin & $-0,04+33,11$ & $-1,12+39,70$ & $+1,37+27,97$ & 0,01 & 0,92 & 0,90 \\
Kraków & $-0,01+34,98$ & $-1,12+41,87$ & $+1,97+27,38$ & 0,01 & 0,88 & 0,96 \\
Legnica & $-0,21+37,59$ & $-1,35+44,66$ & $+1,76+27,43$ & 0,07 & 0,90 & 0,94 \\
Lódź & $+0,17+28,90$ & $-0,87+35,28$ & $+1,67+25,87$ & 0,06 & 0,79 & 0,94 \\
Szczecin & $-0,01+34,60$ & $-1,21+41,70$ & $+1,46+29,22$ & 0,01 & 0,85 & 0,89 \\
Warszawa & $+0,68+25,03$ & $-0,57+32,74$ & $+2,64+26,85$ & 0,41 & 0,69 & 0,99 \\
Wrockaw & $+0,18+30,47$ & $-1,04+38,04$ & $+2,40+24,23$ & 0,04 & 0,86 & 0,98 \\
\hline
\end{tabular}

Źródło: obliczenia własne na podstawie danych z Roczników Demograficznych z różnych lat; GUS, Warszawa. 
Zaobserwowane przekształcenia wzorca płodności wskazują, że im miasto charakteryzowało się większą liczbą mieszkańców, tym były one silniejsze.

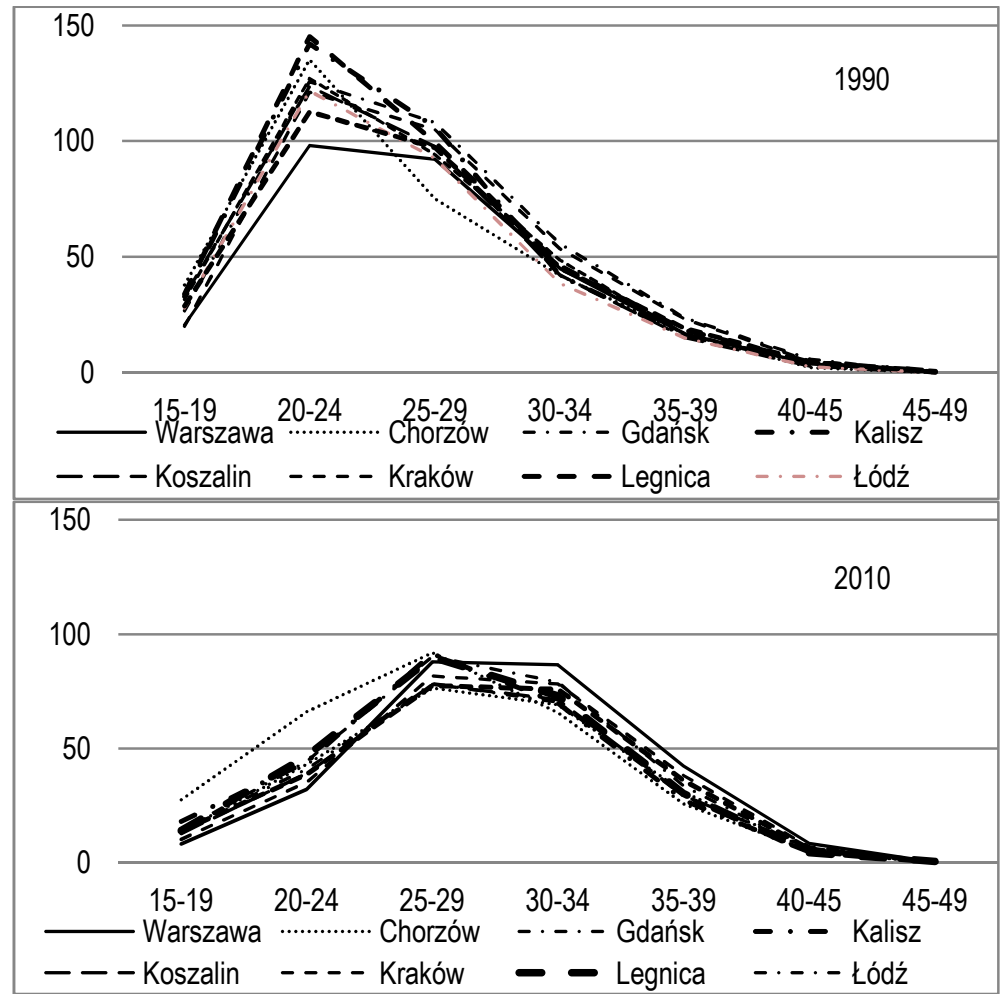

Rysunek 6. Wzorzec płodności w wybranych miastach Polski w latach 1990-2010 Źródło: Rocznik Demograficzny z różnych lat; GUS, Warszawa.

\section{UMIERALNOŚĆ W WYBRANYCH MIASTACH POLSKI}

Kolejnym z omawianych procesów demograficznych jest umieralność. Nie we wszystkich miastach kierunek oraz natężenie zmiany współczynnika umieralność przebiegały podobnie w badanym okresie. Opisując je liniową funkcją trendu, można dostrzec, że w tych latach z roku na rok wartość tej miary najszybciej malała w Chorzowie i Warszawie oraz, nieco już wolniej, w Krakowie. Natomiast wyraźnie rosła w Kaliszu oraz, nieco już wolniej, w Legnicy i Wrocławiu oraz Gdańsku. W pozostałych miastach sytuacja wyglądała nieco inaczej. W początkowym okresie miara ta malała, mniej 
więcej do 2002 roku, a następnie jej wartość rosła. Sytuacja ta dotyczyło takich miast, jak: Łódź (początkowo średnioroczny spadek wartości tej miary wynosił około 0,08 , a następnie rósł z roku na rok o 0,12), Kalisz (odpowiednio o 0,13 oraz 0,20) oraz Szczecin (odpowiednio o 0,08 oraz $0,20)$. Nie można zatem twierdzić, że zmiany w dynamice umieralności zależały od liczby mieszkańców w analizowanych ośrodkach miejskich. Jednocześnie ta różna dynamika zmian spowodowała, że uporządkowanie miast według wartości współczynnika umieralności tylko nieco zmieniło się w czasie. W roku 1990 najniższą umieralnością charakteryzował się Koszalin oraz Szczecin i Gdańsk, a najwyższą Łódź i Chorzów. Dwie dekady później sytuacja dotyczyła odpowiednio Koszalina, Gdańska i Krakowa oraz Łodzi i Chorzowa. Podobnie jak w przypadku dynamiki, natężenie umieralności nie zależało od liczby mieszkańców miast, ale dodatkowo należy zaznaczyć, że z czasem wyraźnie zmalały różnice w poziomie wartości tej miary między tymi ośrodkami miejskimi. Natężenie umieralności stało się w nich nieco mniej zróżnicowane (rysunek 7 i tabela 5).

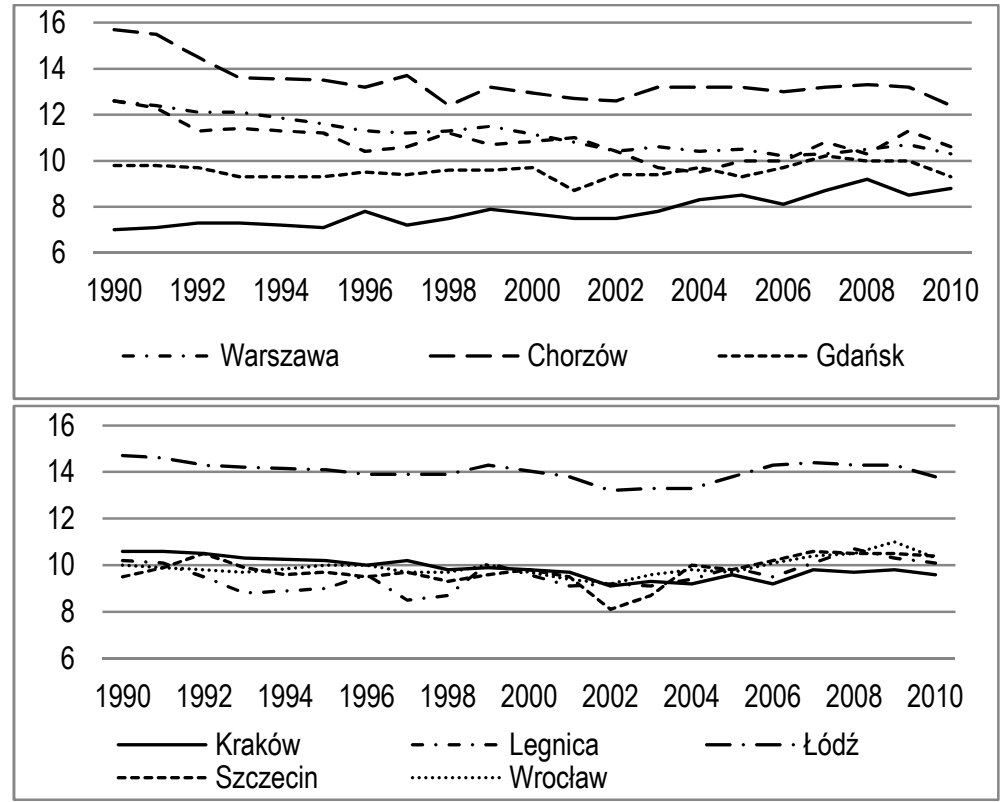

Rysunek 7. Współczynniki umieralności w wybranych miastach Polski w latach 1990-2010 (na 10 tys. ludności)

Źródło: Rocznik Demograficzny z różnych lat; GUS, Warszawa. 
Opisując zmiany współczynnika umieralności, należy pamiętać, że wynikają one z różnych przekształceń cząstkowych współczynników umieralności według wieku (wzorca umieralności). W ostatnich dwóch dekadach krzywa rozkładu uległa wyraźnemu obniżeniu, co oznacza, że we wszystkich grupach wiekowych spadły współczynniki zgonów, a zwłaszcza w tych najmłodszych i najstarszych. Przekształcenia te dotyczyły wszystkich rozważanych miast. Do oceny stopnia tych przekształceń wyznaczyliśmy wskaźniki dynamiki, które liczone są jako iloraz współczynników umieralności odnotowane w roku $2010 \mathrm{w}$ stosunku do roku 1990.

Tabela 5. Liniowa funkcja trendu współczynnika umieralności w wybranych miastach Polski w latach 1990-2010

\begin{tabular}{ccc}
\hline Miasto & Liniowa funkcja trendu & Współczynnik determinacji \\
\hline Chorzów & $-0,09 \cdot t+14,45$ & 0,46 \\
Gdańsk & $+0,01 \cdot t+9,45$ & 0,03 \\
Kalisz & $-0,08 \cdot t+11,72$ & 0,43 \\
Koszalin & $+0,09 \cdot t+6,79$ & 0,81 \\
Kraków & $-0,06 \cdot t+10,49$ & 0,62 \\
Legnica & $+0,04 \cdot t+9,13$ & 0,15 \\
Łódź & $-0,02 \cdot t+14,27$ & 0,11 \\
Szczecin & $+0,03 \cdot t+9,49$ & 0,07 \\
Warszawa & $-0,11 \cdot t+12,37$ & 0,87 \\
Wrocław & $+0,03 \cdot t+9,63$ & 0,18 \\
\hline
\end{tabular}

Źródło: obliczenia własne na podstawie danych z Roczników Demograficznych z różnych lat; GUS, Warszawa.

W grupie wiekowej 0-9 lat spadek umieralności zawierał się w granicach 85-38\%. W Szczecinie i Koszalinie był on najwyższy, a w Chorzowie i Wrocławiu najniższy. W kolejnej grupie wiekowej, tj. 10-19 lat w większości analizowanych miast również odnotowujemy jej spadek (78$-32 \%$ ), ale był on najwyraźniejszy w Chorzowie i Szczecinie, a najsłabszy w Łodzi i Gdańsku. Natomiast w Kaliszu współczynniki umieralności w tej grupie wiekowej wzrosły ponad dwukrotnie. Wśród osób w wieku 20-29 lat spadek umieralności był bardziej zróżnicowany niż w grupach poprzednich i zawierał się w przedziale $90-14 \%$. W Koszalinie i Gdańsku zmiany te były najintensywniejsze, a w Chorzowa i Łodzi najsłabsze. W kolejnej gru-pie wiekowej, tj. 30-39 lat, również zmalała umieralność (87-37\%), zwłasz-cza w Gdańsku, Kaliszu i Szczecinie. Relatywnie najmniejsze zmiany odnotowujemy w Koszalinie i Łodzi. Wśród mieszkańców miast będących w wieku 40-49 lat współczynnik umieralności zmalał relatywnie najsłabiej w stosunku do grup poprzednich (66-30\%). O prawie połowę spadł w Koszalinie i Gdańsku, a w Chorzowie i Łodzi jedynie o jedną trzecią. 


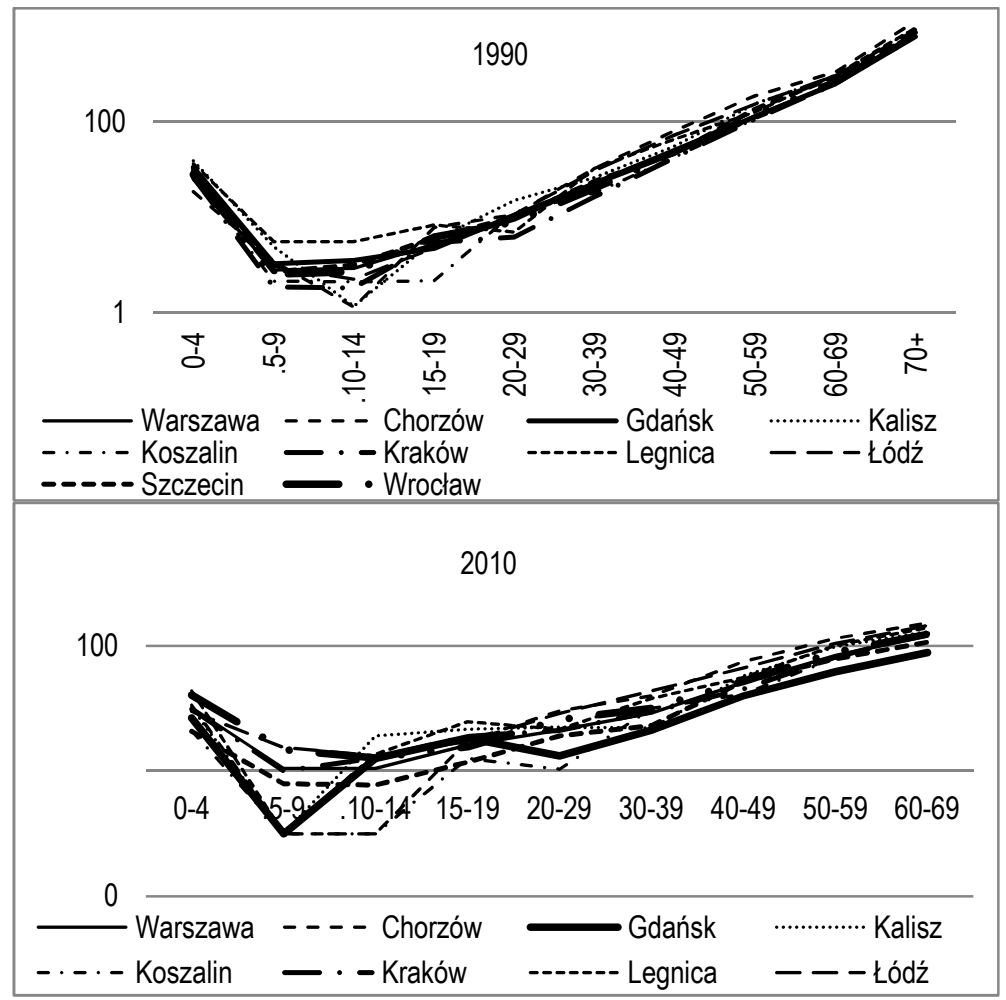

Rysunek 8. Wzorzec umieralności w wybranych miastach Polski w roku 1990 i 2010 (na 10 tys. ludności)

Źródło: Rocznik Demograficzny z różnych lat; GUS, Warszawa.

Grupa wiekowa 50-59 lat charakteryzuje się również spadkiem umieralność (65-20\%), ale w Gdańsku i Szczecinie był on najsilniejszy, a w Legnicy i Łodzi najsłabszy. Natomiast wśród osób w wieku 60-69 lat, gdzie zmiany wartości tej miary kształtowały się między 68-28\%, znowu najwyższy spadek dotyczył Gdańska i Szczecina, a najniższy Koszalina, Krakowa i Legnicy. Ostatnią z omawianych grup były osoby powyżej 70 lat. I tak jak w grupach wcześniejszych, także i tu odnotowujemy spadek umieralności (63-27\%), ale najwyższy dotyczył znowu Gdańska i Szczecinia, a najniższy Łodzi i Koszalina. Z przedstawionych informacji wynika, że dynamika zmian współczynnika umieralności $\mathrm{w}$ młodszych i średnich grupach wiekowych odmiennie kształtowała się w poszczególnych miastach i nie zależała od ich liczby mieszkańców, natomiast powyżej 50 lat dotyczyła tych samych ośrodków miejskich i również nie zależała od liczby mieszkańców. 
Mimo tych zmian w wartościach cząstkowych współczynników umieralności, relacje między miastami były stabilne w czasie (rysunek 8$)^{12}$.

\section{RUCH NATURALNY ORAZ WĘDRÓWKOWY W WYBRANYCH MIASTACH POLSKI}

Syntetycznym wskaźnikiem opisującym wpływ procesów demograficznych na zmiany w liczbie ludności w wyniku zmian w płodności i umieralności jest przyrost naturalny ludności. Dodatkowo na zmiany te wpływa również ruch wędrówkowy ludności. $Z$ informacji przedstawionych na wykresach 9 i 10 wynika, że w latach 1990-2010 współczynniki przyrostu naturalnego oraz współczynniki salda migracji podlegały licznym wahaniom, a ich przebieg odmiennie kształtował się między omawianymi miastami.

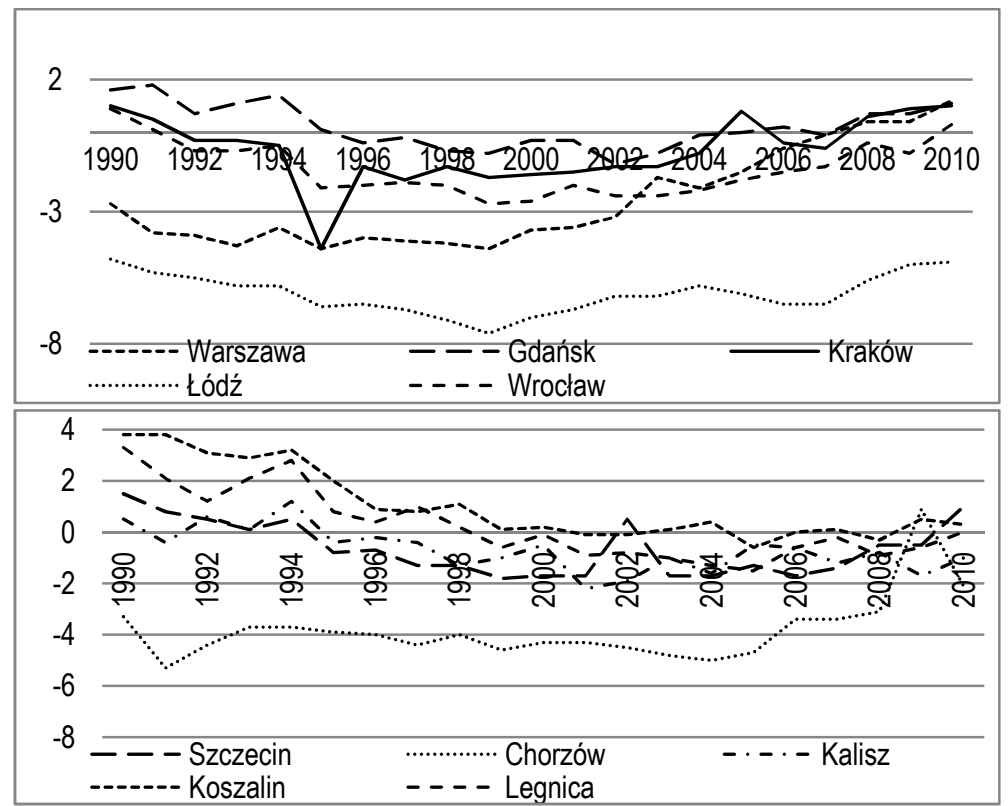

Rysunek 9. Współczynnik przyrostu naturalnego w wybranych miastach Polski w latach 1990-2010

Źródło: Rocznik Demograficzny z różnych lat; GUS, Warszawa.

Uogólniając informacje o zmianach wartości współczynnika przyrostu naturalnego w badanych latach, można stwierdzić, że we wszystkich miastach tendencja ta był ujemna, a zwłaszcza w Warszawie, Wrocławiu i Ko-

${ }^{12}$ Oś OX rysunku 8. jest wyrażona w skali logarytmicznej. 
szalinie. Jednocześnie warto zauważyć, że do połowy badanego okresu intensywny spadek współczynnika przyrostu naturalnego, a następnie w kolejnych latach jego wzrost odnotowano w Gdańsku, Krakowie, Wrocławiu, Warszawie i Łodzi. Mimo różnego natężenia tych zmian, uporządkowanie tych ośrodków miejskich według wartości tej miary nie uległo zasadniczej zmianie w czasie (tabela 6).

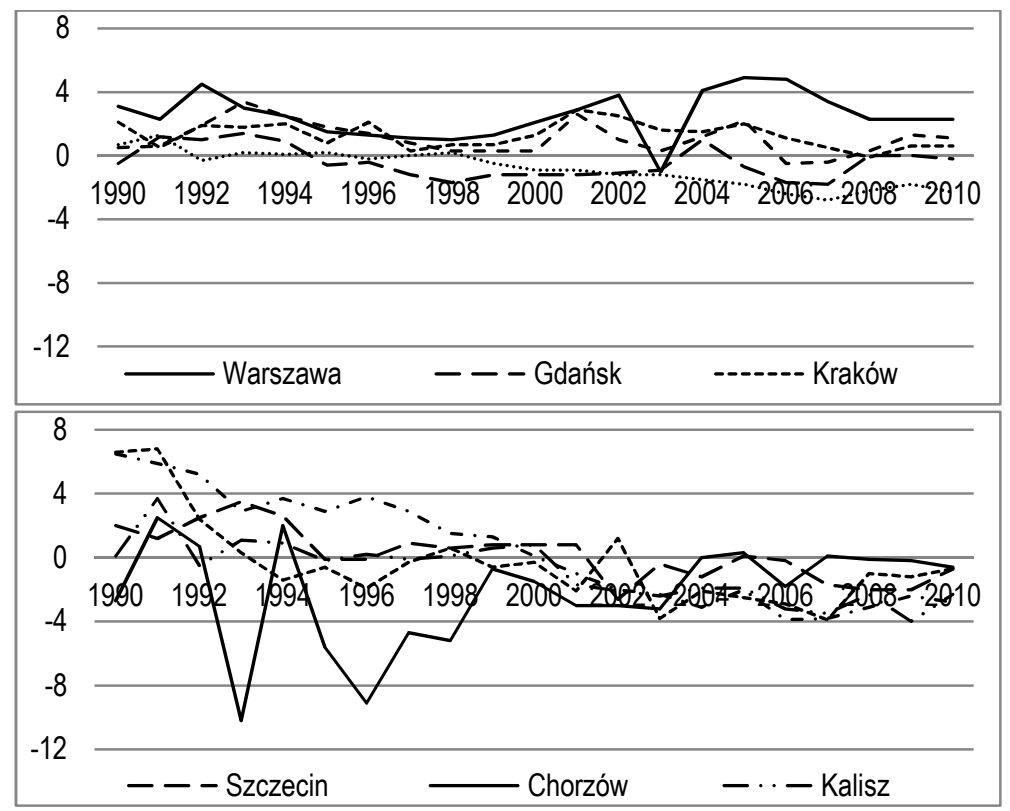

Rysunek 10. Współczynnik salda migracji w wybranych miastach Polski w latach 1990-2010

Źródło: Rocznik Demograficzny z różnych lat; GUS, Warszawa.

Można zatem zauważyć, że w całym badanym okresie w tych ośrodkach miejskich, które charakteryzowały się relatywnie małą liczbą mieszkańców, systematycznie rosła przewaga zgonów nad urodzeniami. Natomiast w miastach ze względnie dużą liczbą mieszkańców, w pierwszych latach badanego okresu, również utrzymywała się przewaga zgonów nad urodzeniami, ale w połowie badanego okresu nastąpiło odwrócenie tych relacji. W rezultacie w roku 2010 dodatnim przyrostem naturalnym charakteryzowała się większość miast Polski o dużej liczbie mieszkańców, poza Łodzią. Wartości bliskie zera dotyczyły ośrodków miejskich z relatywnie małą i średnią liczbą osób w nich zamieszkałych. Ponadto, wyraźnie zmniejszyły się różnice w wartościach przyrostu naturalnego między omawianymi miastami, nie 
powodując jednakże istotnych zmian w relacjach między nimi. Najniższym przyrostem naturalnym odznaczały się Łódź i Chorzów, a najwyższym Gdańsk i Koszalin. Liczba mieszkańców w tych miastach w małym stopniu korelowała z poziomem przyrostu naturalnego, ale determinowała kierunek oraz natężenie tych zmian w czasie.

Tabela 6. Liniowa funkcja trendu współczynnika przyrostu naturalnego w wybranych miastach Polski w latach 1990-2010

\begin{tabular}{ccc}
\hline Miasto & Liniowa funkcja trendu & Współczynnik determinacji \\
\hline Chorzów & $+0,09 \cdot t-4,84$ & 0,20 \\
Gdańsk & $-0,04 \cdot t+0,67$ & 0.09 \\
Kalisz & $-0,09 \cdot t+0,29$ & 0,42 \\
Koszalin & $-0,20 \cdot t+3,21$ & 0,71 \\
Kraków & $+0,05 \cdot t-1,24$ & 0,06 \\
Legnica & $-0,18 \cdot t+2,22$ & 0,65 \\
Łódź & $+0,00 \cdot t-6,12$ & 0,00 \\
Szczecin & $-0,07 \cdot t+0,12$ & 0,16 \\
Warszawa & $+0,25 \cdot t-5,29$ & 0,70 \\
Wrocław & $-0,23 \cdot t-1,04$ & 0,03 \\
\hline
\end{tabular}

Źródło: obliczenia własne na podstawie danych z Roczników Demograficznych z różnych lat; GUS, Warszawa.

Wielkość napływu oraz odpływu ludności do/z analizowanych miast Polski charakteryzują liczne wahania w czasie. W początkowych latach saldo migracji w Warszawie i Krakowie systematycznie malało, aby w kolejnych nieznacznie wzrosnąć. Jednocześnie w miastach tych napływ zawsze przewyższał odpływ, ale jego dynamika była znacznie wyższa na początku lat 90. niż w okresie późniejszym. Podobnym kierunkiem zmian odznaczał się Wrocław, ale z tendencją do wzrostu wartości tej miary w czasie. Przyrost liczby ludności w wyniku migracji było tu nieco wyższy pod koniec rozpatrywanego okresu niż na jego początku. Natomiast w pierwszej dekadzie omawianych lat w Legnicy, Kaliszu i Szczecinie liczba osób napływających znacznie przewyższała ich odpływ, ale z roku na rok relacja ta malała. Spowodowało to, że w kolejnej dekadzie saldo migracji było już ujemne i z czasem wartość ta stale rosła. Podobnym kierunkiem zmian charakteryzowały się Koszalin, Gdańsk i Łódź, ale w ostatnich latach obserwujemy tendencję odwrotną, tj. wzrost salda migracji, ale nadal na wartościach ujemnych. Natomiast w całym badanym okresie w Chorzowie saldo migracji było ujemne, ale $\mathrm{z}$ czasem coraz to mniej osób migrowało $\mathrm{z}$ tego miasta.

Zmiany w kierunku oraz natężeniu salda migracji spowodowały, że relacje między omawianymi miastami według wartości tej miary zmieniały się w czasie. W 1990 roku najwyższym ujemnym saldem migracji charaktery- 
zował się Gdańsk i Chorzów, a najwyższym dodatnim Legnica i Koszalin. Dwie dekady później było to już odpowiednio miasto Legnica i Łódź oraz Wrocław i Warszawa. Można zatem zauważyć, że w pierwszej dekadzie omawianego okresu liczba osób zamieszkałych w danym mieście nie determinowała natężenia salda migracji, ale $\mathrm{w}$ kolejnej dekadzie im miasto z większą liczbę mieszkańców, tym szybciej rosła jego liczba w wyniku ruchu wędrówkowego ludności (tabela 7).

Tabela 7. Liniowa funkcja trendu współczynnika salda migracji w wybranych miastach Polski w latach 1990-2010

\begin{tabular}{ccc}
\hline Miasto & Liniowa funkcja trendu & Współczynnik determinacji \\
\hline Chorzów & $+0,15 \cdot t-3,79$ & 0,07 \\
Gdańsk & $-0,06 \cdot t+0,24$ & 0,14 \\
Kalisz & $-0,25 \cdot t+1,90$ & 0,71 \\
Koszalin & $-0,30 \cdot t+2,96$ & 0,44 \\
Kraków & $-0,04 \cdot t+1,75$ & 0,10 \\
Legnica & $-0,52 \cdot t+6,26$ & 0,91 \\
Łódź & $-0,17 \cdot t+1,05$ & 0,88 \\
Szczecin & $-0,21 \cdot t+2,50$ & 0,62 \\
Warszawa & $+0,03 \cdot t+2,26$ & 0,01 \\
Wrocław & $-0,05 \cdot t+1,68$ & 0,11 \\
\hline
\end{tabular}

Źródło: obliczenia własne na podstawie danych z Roczników Demograficznych z różnych lat; GUS, Warszawa.

Obserwowane różnokierunkowe zmiany w natężeniu salda migracji oraz przyrostu naturalnego sprawiły, że wzrost/spadek liczby ludności w poszczególnych miastach Polski w różnym stopniu wynikał z tych czynników. W latach 90. na spadek liczby ludność w Chorzowie w większym stopniu wpłynął przyrost naturalny, a w Łodzi oraz Wrocławiu migracje. W kolejnej dekadzie w tych miastach to ruch wędrówkowy ludności odgrywał istotniejszą rolę niż przyrost naturalny. Natomiast na początku badanego okresu wzrost liczby mieszkańców Kalisza, Legnicy i Szczecina w większym stopniu był wynikiem migracji, a w Koszalinie - z przyrostu naturalnego. Dekadę później na obserwowany w nich spadek ludności większy wpływ miał ruch wędrówkowy ludności niż relacja między liczbą zgonów a urodzeń. W Warszawie zmiany w liczbie ludności były wynikiem przede wszystkim ruchu migracyjnego, a w Krakowie początkowo kształtowane były one w większym stopniu przez przyrost naturalny, a w kolejnych latach przez migracje. Przeprowadzona analiza prowadzi do wniosku, że liczba osób zamieszkała w tych ośrodkach miejskich nie warunkowała wielkości przyrostu rzeczywistego ludności, a tym samym nie określała zmian w czasie w ich liczbie mieszkańców. 


\section{PODSUMOWANIE}

Przeprowadzone rozważania na temat wpływu liczby osób zamieszkałych w wybranych miasta Polski na dynamikę zmian liczby mieszkańców oraz procesów demograficznych je kształtujących pozwala na wyciągnięcie kilku ogólnych wniosków:

1. W latach 1990-2010 w wybranych miastach Polski z liczbą ludności powyżej 100 tys. wzrost liczby ludności wystąpił w tych ośrodkach miejskich, w których liczba mieszkańców była relatywnie wysoka. Natomiast tam, gdzie była ona względnie mała, trend był ujemny. Jednocześnie natężenie tych zmian w czasie nie zależało od liczby osób zamieszkałych w tych miastach, nie spowodowało też istotnych zmian w uporządkowaniu tych miast według ich liczby mieszkańców.

2. We wszystkich analizowanych miastach skłonność do zawierania małżeństw wyraźnie waha się w czasie, ale ich przebieg kształtował się podobnie w tych ośrodkach. Wyraźnie mniejszą dynamiką zmian współczynnika zawierania małżeństw odznaczały się te ośrodki miejskie, w których liczba mieszkańców była relatywnie wysoka, niż te gdzie ich liczba była względnie mała. Mimo tych zmian, w czasie stałe pozostało uporządkowania badanych miast według wartości tej miary. Ponadto, liczba osób zamieszkałych $\mathrm{w}$ danym ośrodku miejskim jedynie w niewielkim stopniu wpływała na skłonność do zawierania małżeństw. Natomiast im miasto charakteryzowało się większą liczbą mieszkańców, tym większe były też przekształcenia w nim wzorca małżeńskości.

3. W badanym okresie we wszystkim analizowanych miastach odnotowujemy wzrost skłonności do rozwodów, ale im miasto z mniejszą liczbą ludności, tym natężenie tych zmian większe. Jednocześnie w pierwszej dekadzie tego okresu w miastach z relatywnie dużą liczbą ludności natężenie rozwodów był zdecydowanie wyższe niż w tych, gdzie liczba mieszkańców oscylowała wokół 100 tys. Wydaje się, że w drugiej dekadzie tego okresu nie można już dokonać takiego rozróżnienia.

4. Z czasem we wszystkich omawianych miastach zmiany w przebiegu krzywej płodności były podobne, ale im miasto charakteryzowało się większą liczbą ludności, tym wyższa była też i dynamika zmian współczynnika płodności. W początkowych latach badanego okresu możemy zaobserwować, że im miasto z liczbą ludności nieco ponad 100 tys., tym wyższa skłonność do prokreacji, natomiast pod koniec badanego okresu im ośrodek z większą liczbą mieszkańców, tym wyższe wartości współczynnika płodności. Ponadto, wyższy stopień przekształceń wzorca 
płodności odnotowano w tych miastach, gdzie liczba ludności była wyraźnie wyższa niż 100 tys.

5. W latach 1990-2010 na dynamikę zmian współczynnika umieralności oraz jego wartość nie wpływała liczba mieszkańców analizowanych ośrodków miejskich.

6. Liczba osób zamieszkałych w badanych miastach w małym stopniu korelowała z poziomem współczynnika przyrostu naturalnego, ale determinowała jego kierunek oraz natężenie zmian w czasie.

7. W pierwszej dekadzie omawianego okresu liczba osób zamieszkałych $\mathrm{w}$ analizowanych miastach nie determinowała natężenia salda migracji, ale w kolejnej - im miasto odznaczało się większą liczbę mieszkańców, tym szybciej rosła jego liczba w wyniku ruchu wędrówkowego ludności.

Reasumując, obserwowane różnokierunkowe zmiany w natężeniu salda migracji oraz przyrostu naturalnego sprawiły, że wzrost/spadek liczby ludności w poszczególnych miastach Polski w różnym stopniu wynikał z tych czynników. Zatem nie potwierdzono postawionych na wstępie hipotez badawczych, mówiących, że w badanych miastach Polski, które odznaczają się relatywnie dużą liczbą osób w nich zamieszkałych, spadek liczby mieszkańców wynikał przede wszystkim z ujemnego w nich przyrostu naturalnego. Natomiast w tych miastach, gdzie liczba mieszkańców była relatywnie niewielka - głównie z ujemnego salda migracji. Ponadto, w tych miastach, które charakteryzowały się relatywnie dużą liczbą mieszkańców, wzrost liczby mieszkańców wynikał przede wszystkim z dodatniego salda migracji. Natomiast $\mathrm{w}$ miastach z nieco mniejszą liczbą mieszkańców - głównie z dodatniego przyrostu naturalnego.

\section{LITERATURA}

Cigno A. (1991), Economics of the family, Oxford University Press, New York.

Cliquet R. L. (1991), The second demographic transition: fact or fiction, Council of Europe, Strasbourg.

Drobniak A. (2012), Kultura i przemyst kreatywny - doświadczenia, tendencje rozwojowe, nowe obszary badawcze $w$ miastach, [w:] A. Klasik (red.), Kreatywna gospodarka w mieście i aglomeracji, Prace Naukowe UE w Katowicach, 21-40.

Kałuża-Koptac D. (2014), Demograficzne skutki międzynarodowych migracji w wybranych krachach Unii Europejskiej ze szczególnym uzwzględnieniem Polski, [w:] A. Rączaszek i W. Koczur (red.), Polityka społeczna wobec przemian demograficznych, Studia Ekonomiczne UE w Katowicach, 167, 32-42.

Kotowska I. E. (red.) (1999), Przemiany demograficzne $w$ Polsce $w$ latach 90. $w$ świetle koncepcji drugiego przejścia demograficznego, Wydawnictwo SGH, Warszawa. 
Kotowska I., Jóżwiak J., Matysiak A., Baranowska A. (2008), Fertility decline as a response to profound social and labour market changes?, „Demographic Research”, 19, 795-854 .

Majdzińska A. (2011), Procesy demograficzne w średnich i dużych miastach Polski podobieństwa i różnice oraz próba klasyfikacji [w:] M. Balcerowicz-Szkutnik (red.), Wspótczesne problemy demograficzne $w$ dobie globalizacji - aspekty pozytywne i negatywne, Studia Ekonomiczne UE w Katowicach, 95, 155-166.

Matusik S., Pietrzak M.B., Wilk J. (2012), Ekonomiczno-społeczne uwarunkowania migracji wewnętrznych $w$ Polsce $w$ świetle metody drzew klasyfikacyjnych, „Studia Demograficzne", 2/162, 3-28.

Okólski M. (red.) (1990), Teoria przejścia demograficznego, PWE, Warszawa.

Okólski M. (2004), Demografia. Podstawowe pojęcia, procesy i teorie w encyklopedycznym zarysie, Wyd. Naukowe Scholar, Warszawa.

Podogrodzka M. (2012), Indeks Floridy $3 T$ - talent. Propozycja korekty, [w:] A. Klasik (red.), Kreatywna gospodarka w mieście i aglomeracji, Prace Naukowe UE w Katowicach, $65-79$.

Podogrodzka M. (2013), Demografia matych miast Polski - wybrane zagadnienia [w:] K. Heffner i M. Twardzik (red.), Nowoczesne instrumenty polityki rozwoju lokalnego zastosowanie $i$ efekty $w$ matych miastach, Studia Ekonomiczne UE w Katowicach, $144,147-164$.

Rószkiewicz M. (1991), Mechanizm zachowań demograficznych, Monografie i Opracowania SGH, nr 187.

Wróbel M. (2011), Wptyw czynnika ekonomicznego na dzietność w miastach 100-tysięcznych $w$ większych $w$ Polsce wedtug regionów statystycznych $w$ latach 1998-2009, [w:] M. Balcerowicz-Szkutnik (red.), Wspótczesne problemy demograficzne $w$ dobie globalizacji - aspekty pozytywne i negatywne, Studia Ekonomiczne UE w Katowicach, $95,43-53$.

\section{DEMOGRAPHIC PROCESSES IN CITIES OF POLAND}

A b s t r a ct. From the beginning of the 1990s. we have observed the different dynamics of changes of the population of cities Polish due to different rate of demographic processes. fertility, mortality and migration. The purpose of article is to evaluate their impact on these transformations, and as far as the size of the city influences of these changes. The analysis will be conducted using the function of trend and a list of ranked.

K e y w o r d s: demography, cities of Poland, population. 